\title{
PENGARUH SIKLUS PEMANASAN BERTEKANAN-PENDINGINAN TERHADAP KOMPOSISI KIMIA DAN KUALITAS BIOLOGI TEPUNG CAMPOLAY (Pouteria campheciana)
}

\section{THE EFFECT OF AUTOCLAVING-COOLING CYCLE ON CHEMICAL COMPOSITION AND BIOLOGICAL QUALITY OF CAMPOLAY FLOUR (Pouteria campheciana)}

\author{
R. Haryo Bimo Setiarto ${ }^{1 *}$, Lia Amalia ${ }^{2}$, Yusdianti Febriani ${ }^{2}$, Tiana Fitrilia ${ }^{2}$, \\ Nunuk Widhyastuti ${ }^{\mathbf{1}}$ \\ ${ }^{1}$ Laboratorium Mikrobiologi Pangan, Bidang Mikrobiologi, Pusat Penelitian Biologi LIPI \\ Jl. Raya Jakarta-Bogor Km 46, Cibinong Science Center, Cibinong-Bogor 16911, Indonesia \\ 2Program Studi Teknologi Pangan dan Gizi, Fakultas Ilmu Pangan Halal, Universitas Djuanda \\ Jl. Tol Ciawi No1, Ciawi-Bogor, Jawa Barat 16720, Indonesia \\ *e-mail kontributor utama: haryobimo88@gmail.com
}

Diterima : 18-03-2019

Direvisi : 15-04-2019

Disetujui : 22-04-2019

\begin{abstract}
ABSTRAK
Campolay (Pouteria campechiana) memiliki kandungan lengkap serat, pati, kalsium, fosfor, karotenoid, thiamin, riboflavin, niasin, dan vitamin C. Pengolahan Campolay dalam produk tepung dilakukan untuk memperpanjang umur simpan, meningkatkan sifat fungsional, dan diversifikasi produk, sehingga memperluas penggunaan.Kandungan amilosa tinggi pada pati Campolay dapat digunakan sebagai bahan baku pembuatan resistant starch (RS). RS adalah pati yang tidak dapat dicerna oleh enzim pencernaan dan tahan terhadap asam lambung sehingga mampu mencapai usus besar untuk difermentasi oleh bakteri probiotik. RS diklasifikasikan sebagai sumber serat tidak larut dan mampu menurunkan indeks glikemik dan kolesterol, mencegah kanker usus besar, dan membantu penyerapan mineral. Tujuan dari penelitian ini adalah menganalisis pengaruh siklus pemanasan bertekananpendinginan terhadap komposisi kimia dan kualitas biologi tepung Campolay. Irisan campolay diautoklaf $\left(121^{\circ} \mathrm{C}, 15\right.$ menit) dan didinginkan $\left(4^{\circ} \mathrm{C}, 24 \mathrm{jam}\right)$. Perlakuan dilakukan untuk satu, dua dan tiga siklus. Kemudian, irisan campolay dikeringkan $\left(70^{\circ} \mathrm{C}, 7\right.$ jam), digiling dan diayak (100 mesh) untuk mendapatkan tepung campolay termodifikasi. Tepung Campolay termodifikasi dianalisis kadar amilosa, total pati, kadar gula pereduksi, kadar pati cepat cerna, pati lambat cerna, kadar RS, dan daya cerna pati in-vitro dengan tiga kali ulangan. Hasil analisis menunjukkan bahwa perlakuan 1 siklus pemanasan bertekanan-pendinginan menghasilkan peningkatan kadar resistant starch tertinggi (36,23 \%bk) jika dibandingkan dengan perlakuan lainnya dan dapat meningkatkan kadar resistant starch sebesar 2,4 kali lipat jika dibandingkan dengan perlakuan kontrol (15,31 \% bk).
\end{abstract}

Kata Kunci : Tepung campolay (Pouteria campheciana), retrogradasi, resistant starch, pangan fungsional.

\begin{abstract}
Campolay (Pouteria campechiana) has complete content of fiber, starch, calcium, phosphorus, carotenoid, thiamin, riboflavin, niacin, and vitamin C. Campolay processing in flour products was done to extend shelf life, improve functional properties, and diversify products, thus expanding use.High amylose content in Campolay starch can be used as a raw material for resistant starch (RS). RS is a starch that is not able to be digested by the digestive enzyme and resistant to gastric acid that it is able to reach colon to be fermented by probiotic bacteria. RS is classified as insoluble fiber source and is able to decrease the glycemic index and cholesterol, preventing the colon cancer, and helping the absorption of mineral. The purpose of this study was to analyze the effect of the autoclaving-cooling
\end{abstract}


cycle on the chemical composition and biological quality of Campolay flour. Slices of campolay were autoclaved $\left(121^{\circ} \mathrm{C}, 15\right.$ minutes) and cooled $\left(4^{\circ} \mathrm{C}, 24\right.$ hours). The treatment was done for one, two and three cycles. Then, the campolay slices were dried ( $70^{\circ} \mathrm{C}, 7$ hours), milled and sifted (100 mesh) to obtain modified campolay flour. The modified Campolay flour was analyzed for amylose content, total starch, reducing sugar content, Rapid Digestible Starch (RDS), Slowly Digestible Starch (SDS) and Resistant Starch (RS) levels, starch digestibility with three replications. The results of analysis showed that treatment of 1 cycle of autoclaving-cooling (AC-1S) resulted in the highest levels of resistant starch (36.23\% bk) when compared to other treatments. It could increase the resistance of starch levels by 2.4-fold compared to the control treatment (15.31\% bk).

Keywords: Campolay flour (Pouteria campheciana), retrogradation, resistant starch, functional food.

\section{PENDAHULUAN}

ampolay (Pouteria campechiana) merupakan tanaman yang berasal dari Amerika Tengah dan Hindia Barat yang termasuk kedalam tanaman sawo-sawoan, sehingga sering disebut sawo Belanda (Costa et al., 2010). Buah Campolay dilaporkan sebagai bahan pangan yang kaya karotenoid dan berperan sebagai antioksidan maupun hepatoprotektif (Kubola et al., 2010; Aseervatham et al., 2013). Buah campolay memiliki kandungan serat, pati, kalsium, fosfor, karotenoid, thiamin, riboflavin, niasin, vitamin A dan vitamin C (de Lanerolle et al., 2008). Buah Campolay juga mengandung senyawa antioksidan polifenol yaitu asam galat, gallokatekin, katekin, epikatekin, dihidromirisetin, katekin-3-0-galat dan mirisitrin (Elsayed et al., 2016). Komponen sterol dan triterpen dari buah Campolay diketahui juga memiliki aktivitas antimikroba terhadap Escherichia coli, Pseudomonas aeruginosa dan kapang Candida albicans, Trichophyton mentagrophytes (Ragasa et al., 2011). Daun tanaman Campolay yang diekstrak dengan methanol diketahui memiliki efek imunomodulator dengan menstimulasi aktivitas makrofag (Chan-Zapata et al., 2018). Sementara itu senyawa stilbenoid dan glikosida flavonoid dari daun tanaman Campolay juga memiliki aktivitas antimitosis yang dapat menghambat proliferasi sel kanker (Hernandez et al., 2008). Keberadaan senyawa tersebut membuat Campolay berpotensi sebagai alternatif bahan pangan fungsional sehingga saat ini mulai banyak di budidayakan. Pangan fungsional adalah bahan pangan yang memiliki manfaat tertentu untuk mengurangi resiko terjadinya penyakit kronis atau penyakit degeneratif disamping fungsinya untuk memenuhi kebutuhan gizi manusia (Zaragoza et al. 2010). Campolay memiliki prospek dan peluang yang besar sebagai bahan baku industri pangan. Pengolahan buah campolay saat ini masih terbatas yaitu hanya mencapai kurang lebih 10.000 ton/tahun yang sebagian besar diolah menjadi sirup buah campolay (Susilawati, 2015).

Pemanfaatan Campolay saat ini masih terbatas karena kurangnya diversifikasi produk olahan buah campolay. Jika dilihat dari tekstur buahnya, daging buah Campolay yang kaya nutrisi dapat dipakai sebagai bahan campuran es krim, susu kocok (milkshake) dan juga cocok dijadikan bahan baku selai maupun dodol. Salah satu hasil pengolahan Campolay yang sangat potensial untuk dikembangkan adalah tepung campolay. Pertimbangan buah campolay untuk dijadikan tepung dikarenakan kandungan patinya yang tinggi sebagai alternatif sumber karbohidrat dan memiliki kandungan nutrisi yang lengkap. Pengolahan bahan pangan menjadi tepung adalah cara untuk mengawetkan bahan pangan segar sehingga lebih tahan lama, mudah dikemas, memudahkan dalam penyimpanan dan pendistribusian, serta dapat digunakan untuk berbagai keperluan pengolahan diantaranya sebagai bahan campuran cake, brownies, kue talam, biskuit atau kue kering. Di samping itu pengolahan buah campolay dalam bentuk tepung dapat mempertahankan sifat fungsional, mengamankan hasil panen yang melimpah dan sebagai diversifikasi produk, sehingga memperluas penggunaan dan pemasarannya. 
Resistant starch (RS) adalah pati dan produk hasil degradasi pati yang tidak dapat dicerna oleh asam lambung maupun enzim a-amilase dalam usus halus manusia yang sehat tetapi dapat sampai ke usus besar sebagai prebiotik untuk difermentasi oleh mikroflora usus sehingga menghasilkan asam lemak rantai pendek (Sajilata et al., 2006). RS juga memiliki nilai kalori rendah, yaitu sebesar $11,7 \mathrm{KJ} / \mathrm{g}$ RS atau $(1,9 \mathrm{Kkal} / \mathrm{g})$, sehingga dapat dijadikan sebagai ingredien untuk pangan rendah kalori. Efek fisiologis positif RS adalah bertindak sebagai prebiotik fungsional dan meningkatkan produksi asam lemak rantai pendek di usus besar, terutama asam butirat (Setiarto et al.,2015). Terlepas dari manfaat kesehatan terkait dengan fermentasi RS di usus besar, RS diklaim dapat memiliki efek hipokolesterolemia, dapat menurunkan respons indeks glikemik pada bahan pangandan menurunkan resiko kanker kolon (Birt et al., 2013, Nugent, 2005).

Di samping memiliki efek fisiologis terhadap kesehatan, RS juga mempunyai sifat fungsional yang dapat diaplikasikan dalam proses pengolahan pangan. RS dapat digunakan sebagai bahan pengisi (bulking agent) dalam produk pangan rendah gula dan lemak. RS mempunyai daya ikat air yang lebih rendah dibandingkan serat pangan, sehingga tidak berkompetisi dengan ingredien lain untuk memperoleh air, lebih mudah diolah dan tidak menyebabkan produk menjadi lengket. Oleh karena itu, RS dapat berguna dalam formulasi pangan dengan kadar air rendah, seperti cookies dan cracker. Penggunaan RS dalam produk pangan seperti roti, cracker dan muffin memberikan rasa, mouthfeel dan penampakan yang lebih baik dibandingkan bila ditambahkan serat pangan. Kandungan RS dalam beberapa produk pangan telah dilaporkan, seperti pada roti $(2,2-4,3 \%)$, sereal sarapan $(0,0-9,0 \%)$, dan produk pasta (1,3-4,2\%) (Moongngarm, 2013). Englyst et al., (1992) mengelompokkan bahan pangan berdasarkan kandungan RS nya dalam berat kering. Bahan pangan dengan kandungan resistant starch $<1 \%$ termasuk golongan sangat rendah, $1-2,5 \%$ termasuk golongan rendah, $2,5-5 \%$ termasuk golongan sedang, $5-15 \%$ termasuk golongan tinggi dan $>15 \%$ termasuk golongan sangat tinggi.

Resistant starch dapat dikelompokkan menjadi lima tipe, yaitu RS yang secara fisik terperangkap dalam sel-sel tanaman dan matriks bahan pangan (RS1), RS yang secara alami sangat tahan terhadap pencernaan oleh enzim a-amilase (RS2), RS yang dimodifikasi secara fisik (RS3), RS yang dimodifikasi secara kimia (RS4) dan RS yang dibentuk melalui pembentukan ikatan lipid (asam lemak) dengan komponen pati (RS5)(Zaragoza et al., 2010). RS3 merupakan jenis RS yang paling banyak digunakan sebagai bahan baku pangan fungsional (Sugiyono et al., 2009). RS tipe 3 juga disukai karena relatif paling tahan panas dibandingkan RS tipe lainnya sehingga RS3 dapat mempertahankan sifatnya selama proses pengolahan pangan. Resistant starch tipe III (RS3) dapat dihasilkan dari proses pemanasan suhu tinggi dan pendinginan secara berulang (Faridah et al., 2013). Pembentukan RS3 paling optimum berlangsung bila suhu autoklaf sebesar $121^{\circ} \mathrm{C}$ (Sugiyono et al., 2009). Menurut Sajilata et al. (2006), perlakuan pemansan bertekanan-pendinginan dapat meningkatkan produksi RS hingga $9 \%$.

Proses pemanasan suhu tinggi dengan autoklaf, mengakibatkan pati tergelatinisasi secara sempurna. Proses penyimpanan suhu rendah dari pasta pati yang dihasilkan akan mempercepat terjadinya retrogradasi pati (Mutungi et al., 2009). Pada saat gelatinisasi pati, sifat birefringence granula pati hilang akibat penambahan air secara berlebih dan pemanasan pada waktu dan suhu tertentu, sehingga granula pati membengkak dan tidak dapat kembali pada kondisi semua (irreversibel) (Yadav et al., 2009). Proses pemanasan bertekananpendinginan secara berulang dapat menyebabkan semakin banyaknya pembentukan fraksi amilosa teretrogradasi atau terkristalisasi. Fraksi amilosa yang berikatan dengan fraksi amilosa lainnya melalui ikatan hidrogen membentuk struktur double helix (Karim et al., 2000).

Proses pemanasan bertekanan-pendinginan berulang dapat menyebabkan terjadinya peningkatan penyusunan kembali ikatan hidrogen antara amilosa-amilosa dan amilosa- 
amilopektin dan peningkatan pembentukan struktur kristalin yang lebih sempurna yang berakibat pada peningkatan kadar RS3 (Leong et al., 2007). Faktor lain yang berpengaruh terhadap pembentukan RS3 melalui proses autoclaving-cooling adalah konsentrasi pati, suhu autoklaf, konsentrasi amilosa dan amilopektin, panjang rantai amilosa, dan jumlah siklus autoclaving-cooling (Sajilata et al., 2006). Penelitian ini bertujuan menganalisis pengaruh siklus pemanasan bertekanan-pendinginan terhadap komposisi kimia dan kualitas biologi tepung Campolay.

\section{METODE PENELITIAN}

\section{Bahan dan Alat}

Bahan baku yang digunakan adalah buah campolay masak penuh (berkulit kuning kehijaun dan keras) tapi belum matang yang diperoleh dari daerah Cipatat, Bandung. Bahanbahan lain yang digunakan dalam penelitian ini adalah air, aquades, $\mathrm{HCL} 1 \mathrm{~N}, \mathrm{NaOH} 30 \%$, etanol 95\%, $\mathrm{NaOH} 1 \mathrm{~N}$, asam asetat $1 \mathrm{~N}$, larutan iod, KCI-HCL, Pepsin, larutan buffer fosfat, porcine pancreatin, enzim a-amilase, enzim amiloglukosidase, maltosa, glukosa, $\mathrm{KOH}$, buffer sodium asetat, etanol $95 \%$, asam asetat, larutan lugol $\left(\mathrm{I}_{2}: \mathrm{KI}\right)$, fenol $95 \%, \mathrm{H}_{2} \mathrm{SO}_{4}$.

Alat yang digunakan adalah peeler, timbangan, baskom, tisu, ayakan, oven listrik, blender, gelas ukur, autoklaf, refrigerator, oven, vorteks, desikator, cawan porselen, neraca analitik, timbangan, kertas saring, sudip, beaker glass, corong, soxhlet, labu takar, labu kjeldahl, destilasi, buret, penangas bergoyang, mortar, tabung reaksi, erlenmeyer, pipet tetes, pipet mikro, muffle furnance, tabung reaksi dan spektofotometer UV-Vis.

\section{Tempat dan Waktu Penelitian}

Penelitian dilaksanakan pada bulan Januari sampai dengan Mei 2018 di Laboratorium Sains, Laboratorium Pengolahan Pangan Universitas Djuanda Bogor, dan Laboratorium Mikrobiologi Pangan - Pusat Penelitian Biologi LIPI Cibinong Bogor.

\section{Perlakuan Siklus Pemanasan Bertekanan-Pendinginan untuk Tepung Campolay}

Buah Campolay (Pouteria campechiana) dikupas, dicuci, dan diiris dengan ketebalan \pm $5 \mathrm{~mm}$, kemudian direndam dalam larutan $\mathrm{NaCl} 1 \%$ dengan perbandingan (3:4) selama satu jam untuk menghilangkan kandungan senyawa anti nutrisinya. Irisan Campolay dicuci dengan akuades dan ditiriskan. Perlakuan siklus pemanasan bertekanan-pendinginan dilakukan sesuai dengan tahapan yang ditunjukkan oleh Gambar 1. Irisan Campolay diautoklaf $\left(121{ }^{\circ} \mathrm{C}, 15\right.$ menit), dengan perbandingan irisan Campolay : akuades(1:2), kemudian didinginkan di refrigerator $\left(4^{\circ} \mathrm{C}, 24\right.$ jam). Selanjutnya, irisan Campolay yang diolah dikeringkan $\left(70{ }^{\circ} \mathrm{C}, 16\right.$ jam) dengan oven sampai diperoleh kadar air 12\%, kemudian dilakukan penepungan dengan menggunakan pin disk mill. Tepung Campolay yang dihasilkan diayak untuk mendapatkan sampel tepung Campolay berukuran 100 mesh. Untuk menentukan pengaruh jumlah siklus pemanasan bertekanan-pendinginan terhadap komposisi kimia dan kualitas biologi tepung Campolay,dilakukan pengelompokan tepung Campolay dengan menggunakan Rancangan Acak Lengkap (RAL) sebagai berikut: 1) Kode AC-1S (1 siklus Autoclaving-Cooling); 2) Kode AC-2S (2 siklus Autoclaving-Cooling); 3) Kode AC-3S (3 siklus Autoclaving-Cooling).

\section{Analisis kimia terhadap tepung Campolay kaya RS}

Sampel tepung Campolay dilakukan analisis kadar amilosa (Faridahet al., 2013), kandungan total pati (Faridahet al., 2013), kadar gula pereduksi (Faridahet al., 2013), kadar pati cepat cerna (Rapid Digestible Starch/ RDS), pati lambat cerna (Slowly Digestible Starch/ $S D S$ ) dan kadar resistant starch (RS) (Englyst et al., 1992), daya cerna pati in-vitro 
(Anderson et al., 2002) sebanyak tiga kali ulangan (triplo) dimana satu sampel yang dianalisis diulang 3 kali.
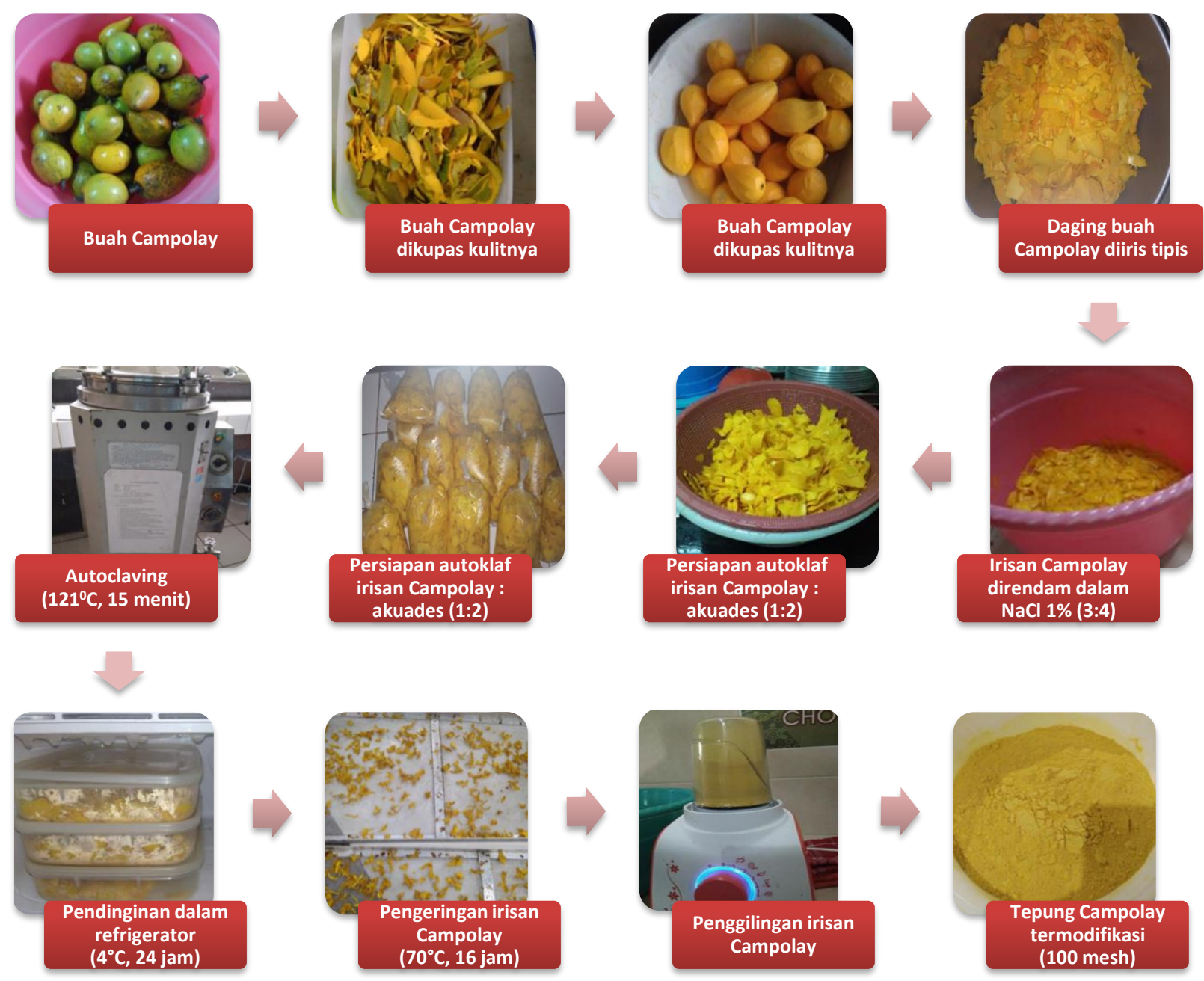

Gambar 1. Produksi tepung Campolay modifikasi dengan siklus pemanasan bertekanan-pendinginan

\section{Analisis kadar total pati}

Analisis kadar total pati dilakukan dengan mengacu pada metode Faridah et al., (2013). Sebanyak $1 \mathrm{~g}$ tepung Campolay dimasukkan secara perlahan ke dalam $100 \mathrm{~mL}$ etanol 95\% dan dihomogenkan menggunakan pengaduk magnetik. Suspensi tepung Campolay disaring menggunakan kertas saring. Kertas yang berisi residu tepung Campolay didiamkan semalam dalam desikator. Residu tepung Campolay ditimbang sehingga diketahui beratnya. Setelah itu tepung Campolay dihaluskan dengan mortar. Sebanyak $40 \mathrm{mg}$ tepung Campolay yang telah dihaluskan ditambah dengan $20 \mathrm{~mL}$ akuades, lalu diautoklaf pada suhu $105^{\circ} \mathrm{C}$ selama 1 jam. Setelah diautoklaf, sampel didinginkan pada suhu kamar lalu diencerkan dengan akuades sebanyak 40 kali.

Sebanyak 0,5 $\mathrm{mL}$ sampel tepung Campolay dimasukkan ke dalam tabung reaksi, kemudian ditambahkan 0,5 mL fenol $5 \%$ dan dihomogenkan dengan menggunakan vorteks. Sebanyak 2,5 mL larutan $\mathrm{H}_{2} \mathrm{SO}_{4}$ pekat lalu ditambahkan secara cepat ke dalam tabung reaksi, sehingga terjadi reaksi eksoterm yang menghasilkan panas. Larutan sampel kemudian didiamkan selama 10 menit pada suhu ruang, diaduk dengan vorteks dan didiamkan kembali 
selama 20 menit pada suhu ruang. Nilai absorbansi diukur dengan spektrofotometer UV-Vis pada panjang gelombang $490 \mathrm{~nm}$. Kadar glukosa $(\mathrm{mg} / \mathrm{mL})$ ditentukan dengan menggunakan kurva standar. Kadar total gula (persen bk) diperoleh dari kurva standar, sedangkan kadar total pati (persen bk) dihitung dengan mengalikan kadar total gula dengan faktor 0,9.

$$
\text { Kadar Total Pati }(\% \mathrm{bk})=\frac{G}{W} \times \vee \times \mathrm{FPx} 100 \% \times 0,9
$$

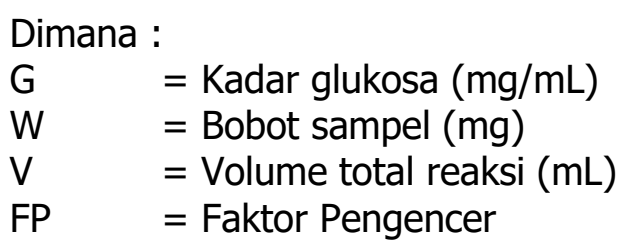

\section{Analisis kadar amilosa dan amilopektin}

Analisis kadar amilosa dan amilopektin dilakukan dengan merujuk pada metode Faridah et al., (2013). Sebanyak 100,0 mg sampel tepung Campolay yang telah diekstraksi kandungan patinya dimasukkan ke dalam labu takar $100 \mathrm{~mL}$, kemudian ditambahkan $1,0 \mathrm{~mL}$ etanol 95\% dan 9,0 mL larutan $\mathrm{NaOH} 1 \mathrm{~N}$. Labu takar ini lalu dipanaskan dalam penangas air pada suhu $95^{\circ} \mathrm{C}$ selama 10 menit. Setelah didinginkan, larutan gel pati Campolay ditambahkan akuades sampai tanda tera dan dihomogenkan. Dari labu takar dipipet 5,0 mL larutan gel pati Campolay dan dipindahkan ke dalam labu takar $100 \mathrm{~mL}$. Ke dalam labu takar tersebut, ditambahkan 1,0 $\mathrm{mL}$ larutan asam asetat $1 \mathrm{~N}$ dan 2,0 $\mathrm{mL}$ larutan iod, lalu ditambah akuades hingga tanda tera. Larutan sampel dibiarkan selama 20 menit pada suhu ruang sebelum diukur absorbansinya dengan spektrofotometer UV-Vis pada panjang gelombang $625 \mathrm{~nm}$. Kadar amilosa (\% bobot kering) ditentukan dengan menggunakan persamaan kurva standar larutan amilosa.

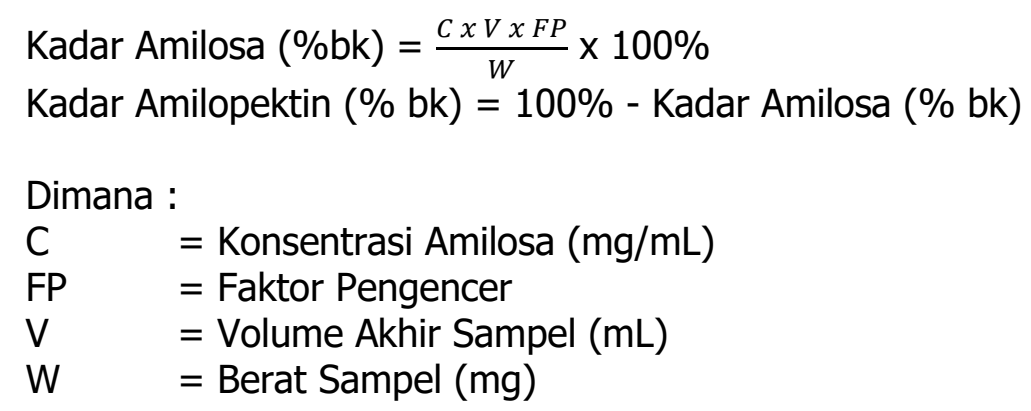

\section{Analisis kadar gula pereduksi}

Analisis kadar gula pereduksi dilakukan dengan mengacu pada metode Faridah et al., (2013). Sebanyak 1,0 g tepung Campolay dimasukkan secara perlahan ke dalam 100,0 mL etanol 95\% dan dihomogenkan dengan menggunakan pengaduk magnetik. Suspensi tepung Campolay tersebut kemudian disaring menggunakan kertas saring. Kertas yang berisi residu tepung Campolay didiamkan semalam di dalam desikator. Setelah kering, tepung Campolay dihaluskan dengan mortar. Sebanyak $20,0 \mathrm{mg}$ tepung Campolay yang telah dihaluskan ditambahkan dengan $10,0 \mathrm{~mL}$ akuades, kemudian dipanaskan dalam autoklaf $105^{\circ} \mathrm{C}$ selama 1 jam. Setelah pemanasan selesai, pasta pati didinginkan pada suhu kamar dan dilakukan pengenceran 10 kali sebelum digunakan.

Prosedur pengujian kadar gula pereduksi adalah sebagai berikut : $1 \mathrm{~mL}$ sampel dimasukkan kedalam tabung reaksi, kemudian ditambahkan $2 \mathrm{~mL}$ pereaksi DNS (3,5- Dinitro Salisic Acid). Sampel tersebut ditempatkan dalam air mendidih selama 5 menit. Selanjutnya diencerkan dengan $10 \mathrm{~mL}$ akuades, dibiarkan sampai dingin pada suhu ruang. Absorbansi 
diukur pada Spektrofotometer UV-Vis pada panjang gelombang $540 \mathrm{~nm}$. Gula pereduksi (\% bobot kering) ditentukan dengan menggunakan persamaan kurva standar larutan glukosa.

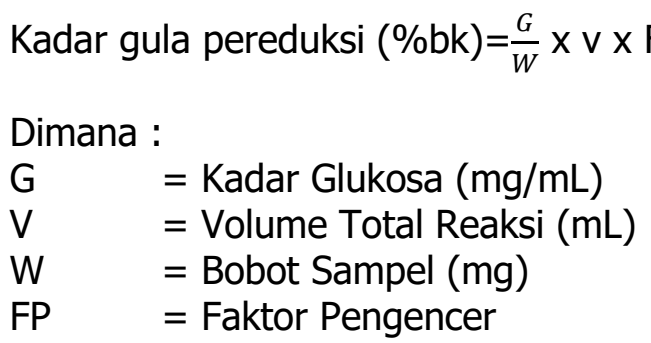

\section{Analisis daya cerna pati in-vitro}

Analisis daya cerna pati secara in-vitro dilakukan dengan mengacu pada metode Anderson et al., (2002). Sampel tepung Campolay diekstrak terlebih dahulu kandungan patinya. Sebanyak $1,0 \mathrm{~g}$ sampel pati Campolay dimasukkan ke dalam erlenmeyer $250 \mathrm{~mL}$, lalu ditambahkan dengan 100,0 mL akuades. Labu erlenmeyer ditutup dengan alumunium foil dan dipanaskan dalam penangas air hingga mencapai suhu $90^{\circ} \mathrm{C}$ sambil terus diaduk, lalu didinginkan. Sebanyak 2,0 mL larutan sampel tersebut dipipet ke dalam tabung reaksi bertutup, lalu ditambahkan 3,0 mL akuades dan 5,0 mL larutan buffer fosfat pH 7,0. Masingmasing sampel dibuat dua kali, yang salah satunya digunakan sebagai blanko. Tabung ditutup dan diinkubasikan pada suhu $37^{\circ} \mathrm{C}$ selama 15 menit. Larutan sampel dan blanko diangkat dan ditambahkan 5,0 mL larutan enzim a-amilase $(1 \mathrm{mg} / \mathrm{mL}$ dalam larutan buffer fosfat $\mathrm{pH} 7,0)$. Kedua tabung tersebut diinkubasi kembali selama 30 menit, lalu dipindahkan sebanyak $1,0 \mathrm{~mL}$ sampel ke dalam tabung reaksi bertutup berisi 2,0 mL larutan DNS (asam dinitrosalisilat). Larutan dipanaskan dalam air mendidih selama 12 menit, lalu didinginkan dengan air mengalir. Sebanyak 10,0 mL akuades kemudian ditambahkan, lalu diaduk hingga homogen dengan menggunakan vorteks. Larutan sampel dan blanko tersebut kemudian diukur absorbansinya dengan spektrofotometer UV-Vis pada panjang gelombang $520 \mathrm{~nm}$. Daya cerna pati (\%) dihitung dengan menggunakan rumus sebagai berikut:

$$
\frac{\text { Kadar maltosa sampel - Kadar maltosa blanko sampel }}{\text { Kadar maltosa pati murni - Kadar maltosa blanko pati murni }} \times 100
$$

\section{Analisis Kadar Pati Cepat Cerna (Rapid Digestible Starch/ RDS), Pati Lambat Cerna (Slowly Digestible Starch / SDS) dan RS (Resistant Starch) Tepung Campolay}

Komposisi pati yang dianalisis meliputi kadar RDS, SDS dan RS ditentukan dengan menggunakan metode Englyst et al., (1992). Sampel tepung Campolay diekstrak terlebih dahulu kandungan patinya. Sebanyak $1 \mathrm{~g}$ pati Campolay ditempatkan dalam tabung sentrifus. Sampel dicuci menggunakan $8 \mathrm{~mL}$ etanol $80 \%$ selanjutnya disentrifus pada kecepatan $554 \mathrm{x}$ g selama 10 menit dan diulangi dua kali. Residu pati Campolay ditambah $20 \mathrm{~mL}$ buffer sodium

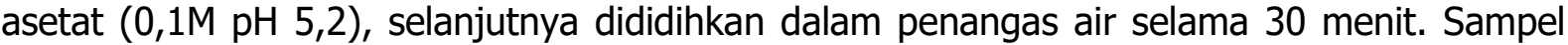
didinginkan dan ditambah $5 \mathrm{~mL}$ larutan enzim yang mengandung ekstrak pankreatin dan amiloglukosidase. Larutan enzim disiapkan dengan cara mensuspensikan 3,0 g pankreatin (Sigma, Cat. No. P7545) ke dalam $20 \mathrm{~mL}$ air deionisasi, selanjutnya distirer selama 10 menit pada suhu ruang dan disentrifus dengan kecepatan $1500 \times \mathrm{g}, 4^{\circ} \mathrm{C}$ selama 10 menit. Sebanyak $13.5 \mathrm{~mL}$ supernatan pankreatin ditambah $0.25 \mathrm{~mL}$ amiloglukosidase $210 \mathrm{U}$ (Sigma Cat. No. A7095) dan 1,25 mL air deionisasi. Selanjutnya sampel diinkubasi dalam shaker waterbath pada suhu $37{ }^{\circ} \mathrm{C}$ selama 20 menit untuk menentukan kadar RDS dan 120 menit untuk SDS. RDS dinyatakan sebagai total pati yang dicerna selama 20 menit pertama, dan SDS dinyatakan sebagai total pati yang dicerna antara 20 dan 120 menit. 
Sampel yang telah dianalisis RDS dan SDS disentrifus (15 menit, $3000 \times \mathrm{g}$ ), bagian residu diambil dan dicuci dengan 10,0 mL akuades. Proses sentrifugasi diulang lagi dengan cara yang sama seperti di atas dan residunya kembali diambil dan dicuci. Ke dalam residu sampel di atas ditambahkan 3,0 mL akuades dan 1,5 mL larutan $\mathrm{KOH} 10 \mathrm{M}$, lalu diaduk dengan menggunakan vorteks dan didiamkan selama 30 menit pada suhu ruang. Secara berturut-turut ke dalam sampel tersebut ditambahkan 2,75 $\mathrm{mL} 2 \mathrm{M} \mathrm{HCl}$ dan 1,5 mL buffer sodium asetat $\mathrm{pH}$ 4,75 dan $40 \mu \mathrm{l}$ enzim amiloglukosidase $210 \mathrm{U}$. Sebelum diinkubasi pada suhu $60^{\circ} \mathrm{C}$ selama 45 menit, sampel diaduk dengan menggunakan vorteks. Sampel disentrifus (15 menit, 3000x g), kemudian bagian supernatan diambil dan dimasukkan ke dalam labu takar. Bagian residu dicuci dengan $10 \mathrm{~mL}$ akuades, lalu disentrifus kembali. Bagian supernatan kemudian dicampurkan dengan supernatan sebelumnya. Sebanyak $25-1.000 \mathrm{~mL}$ sampel diencerkan dengan akuades (tingkat pengenceran tergantung pada kandungan RS dalam sampel).

Sebanyak $1 \mathrm{~mL}$ sampel ditambahkan $2 \mathrm{~mL}$ pereaksi DNS (asam dinitrosalisilat). Setelah itu dipanaskan dalam penangas air dengan suhu air $\left(100^{\circ} \mathrm{C}\right)$ selama 10 menit lalu didinginkan pada suhu ruang. Sampel kemudian diencerkan dengan penambahan $10 \mathrm{~mL}$ akuades dan diukur menggunakan spektrofotometer pada panjang gelombang $550 \mathrm{~nm}$. Akuades digunakan sebagai blanko. Kurva standar dibuat menggunakan larutan glukosa standar, yaitu $2 \mathrm{mg} / \mathrm{ml}$ sebagai larutan induk. Larutan kerja yang digunakan sebagai standar adalah $0,2 \mathrm{mg} / \mathrm{mL} ; 0,4$ $\mathrm{mg} / \mathrm{mL} ; 0,6 \mathrm{mg} / \mathrm{mL} ; 0,8 \mathrm{mg} / \mathrm{mL} ; 1,0 \mathrm{mg} / \mathrm{mL}$. Persen RS diperoleh dengan mengalikan persen glukosa dengan faktor koreksi 0,9 .

$$
\begin{aligned}
& \operatorname{RDS}(\%)=\frac{G 20 \times 0.9 \times F}{W} \times 100 \\
& \text { SDS (\%) }=\frac{(G 120-G 20) \times 0.9 \times F}{W} \times 100 \\
& \text { RS }(\%)=100-\text { VRDS - RDS - SDS }
\end{aligned}
$$

Dimana :

G20: Nilai absorbansi untuk kadar glukosa setelah inkubasi 20 menit

G120: Nilai absorbansi untuk kadar glukosa setelah inkubasi 120 menit

F: $100 /$ absorbansi

W: bobot sampel

\section{Rancangan Percobaan dan Analisis Data}

Untuk menentukan pengaruh jumlah siklus pemanasan bertekanan-pendinginan terhadap komposisi kimia dan kualitas biologi tepung Campolay dilakukan perancangan percobaan dengan Rancangan Acak Lengkap (RAL). Analisis ragam dilakukan terhadap data yang diperoleh dengan menggunakan Software SPSS 17,0. Selanjutnya untuk peubah yang menunjukkan beda nyata dilakukan perbandingan nilai tengah dengan uji jarak berganda Duncan (Duncan Multiple Range Test) pada taraf signifikansi 5\%.

\section{HASIL DAN PEMBAHASAN}

\section{Kadar Total Pati Tepung Campolay Termodifikasi}

Kadar total pati tepung Campolay mengalami penurunan setelah diberi perlakuan pemanasan bertekanan-pendinginan beberapa siklus. Perlakuan pemanasan bertekananpendinginan secara berulang kali yaitu 1, 2, dan 3 siklus (AC-1S, AC-2S, AC-3S) menunjukkan kadar total pati yang lebih rendah jika dibandingkan dengan perlakuan kontrol seperti pada Gambar 2. 


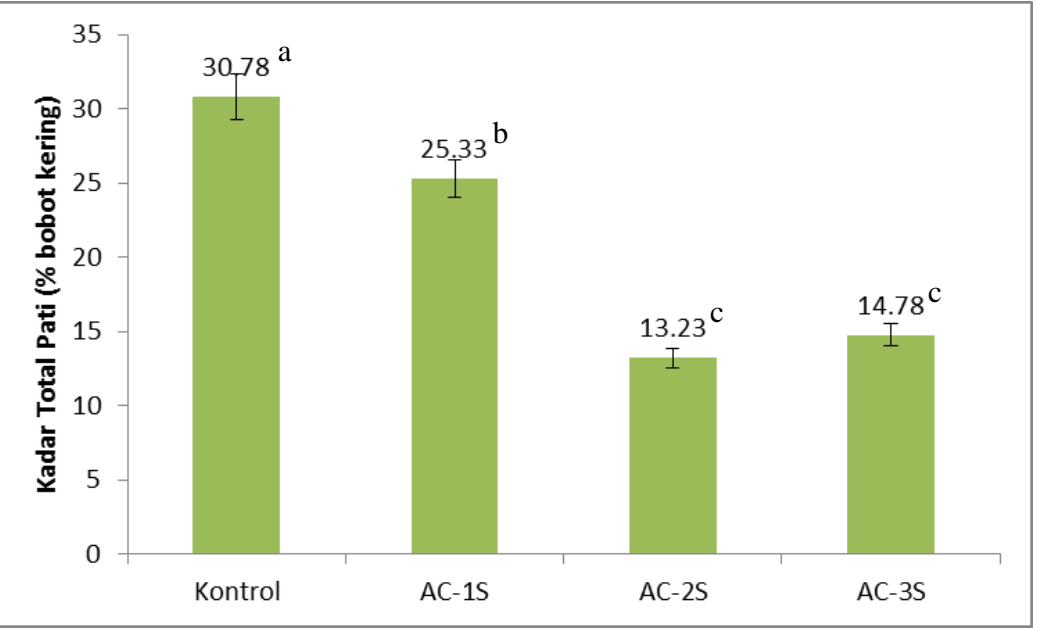

Gambar 2. Pengaruh siklus pemanasan bertekanan-pendinginan terhadap kadar total pati tepung Campolay

Huruf yang berbeda pada diagram batang menunjukkan nilai yang berbeda nyata dengan taraf nyata $95 \%$, ( $a=$ 5\%), setelah dilakukan uji Duncan pada SPSS 17.0

Semakin banyak jumlah siklus pemanasan bertekanan-pendinginan yang dilakukan secara berulang kali berpengaruh signifikan $(p<0,05)$ terhadap semakin rendahnya kadar total pati tepung Campolay termodifikasi. Pemanasan autoklaf mengakibatkan peningkatan degradasi pati Campolay sehingga terjadi peningkatan level kerusakan granula pati. Degradasi terjadi akibat putusnya ikatan glikosidik pada fraksi pati baik pada ikatan linier a-1,4 amilosa dan ikatan percabangan a-1,6 amilopektin akibat pemanasan autoklaf (Zaragoza et al. 2010 dan Vatanasuchart et al. 2012). Hasil ini sesuai dengan penelitian Sugiyono et al. (2009) dan Faridah et al. (2013) yang melakukan siklus pemanasan bertekanan-pendinginan secara berulang kali pada pati garut. Hasil penelitian Setiarto et al. (2018) yang melakukan siklus pemanasan bertekanan-pendinginan secara berulang pada tepung talas termodifikasi semakin memperkuat hasil penelitian ini.

\section{Kadar Gula Pereduksi Tepung Campolay Termodifikasi}

Kadar gula pereduksi tepung Campolay mengalami penurunan setelah diberi perlakuan pemanasan bertekanan-pendinginan berulang kali dengan beberapa siklus. Perlakuan pemanasan bertekanan-pendinginan berulang dengan 1, 2, dan 3 siklus (AC-1S, AC-2S, AC-3S) menunjukkan kadar gula pereduksi yang lebih rendah jika dibandingkan dengan perlakuan kontrol seperti pada Gambar 3. Semakin banyak jumlah siklus pemanasan bertekanan-pendinginan yang diaplikasikan berpengaruh signifikan $(p<0,05)$ terhadap semakin rendahnya kadar gula pereduksi tepung Campolay (pada Gambar 2). Hasil ini sesuai dengan penelitian yang dilakukan oleh Nurhayati et al. (2014) yang melakukan perlakuan fermentasi spontan dan siklus pemanasan bertekanan-pendingnan pada tepung pisang termodifikasi. Di samping itu hasil penelitian Sugiyono et al. (2009) dan Faridah et al. (2013) yang melakukan siklus pemanasan bertekanan-pendinginan secara berulang kali pada pati garut semakin membuktikan bahwa perlakuan perlakuan pemanasan bertekanan-pendinginan berulang kali dapat menurunkan kadar gula pereduksi pada bahan pangan. 


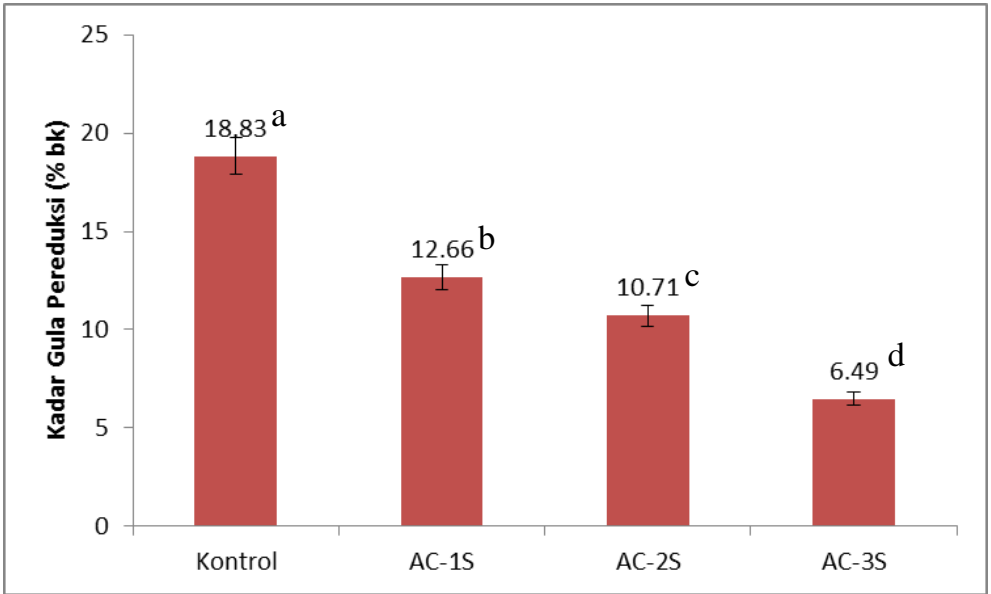

Gambar 3. Pengaruh siklus pemanasan bertekanan-pendinginan terhadap kadar gula pereduksi tepung Campolay

Huruf yang berbeda pada diagram batang menunjukkan nilai yang berbeda nyata dengan taraf nyata $95 \%$, ( $a=$ 5\%), setelah dilakukan uji Duncan pada SPSS 17.0

Penurunan kadar gula pereduksi pada tepung campolay yang diberi perlakuan siklus pemanasan bertekanan-pendinginan disebabkan oleh terjadinya reaksi Maillard. Reaksi Maillard terjadi karena adanya interaksi antara asam amino dan gula pereduksi yang terkandung dalam tepung campolay pada suhu tinggi (Bastos et al. 2012). Reaksi Maillard yang terjadi menyebabkan jumlah gula pereduksi yang terukur dalam analisis sampel yang mengalami pemanasan bertekanan menurun, karena sudah digunakan dalam reaksi Maillard. Salah satuf aktor yang mempengaruhi reaksi Maillard yaitu suhu dan waktu pemanasan. Semakin lama waktu dan semakin tinggi suhu yang digunakan serta semakin banyak siklus pemanasan bertekanan-pendinginan yang diaplikasikan, maka reaksi Maillard akan terjadi lebih banyak lagi sehingga menyebabkan penurunan kadar gula pereduksi dengan signifikan.

\section{Kadar Amilosa dan Amilopektin Tepung Campolay Termodifikasi}

Pati tersusun atas komponen amilosa dan amilopektin. Amilosa mempunyai struktur lurus, yaitu a-D-glukosa yang dihubungkan satu sama lain dengan ikatan glikosidik a-1,4 dan memiliki dengan berat molekul sekitar $10^{5}-10^{6}$. Amilopektin mempunyai struktur bercabangcabang, yaitu titik percabangannya dihubungkan dengan ikatan glikosidik a-1,6. Karim et al., (2000) melaporkan bahwa jumlah a-D-glukosa penyusun titik percabangan pada amilopektin, yaitu 20-30 unit anhidroglukosa. Amilopektin memiliki berat molekul lebih tinggi bila dibandingkan dengan amilosa, yaitu sekitar $10^{6}-10^{9}$. Pada jenis pati yang rekat (adesif) amilosa dalam pati berkisar 20-30\%. Karakteristik dari amilosa dalam suatu larutan adalah kecenderungan membentuk koil yang sangat panjang dan fleksibel yang selalu bergerak melingkar. Dalam masakan, amilosa memberikan efek keras bagi pati, sedangkan amilopektin bersifat merangsang terjadinya proses mekar (puffing) dimana produk yang berasal dari pati yang kandungan amilopektinnya tinggi akan bersifat ringan, berpori, kering, dan renyah (Moongngarm, 2013).

Hasil penelitian menunjukkan bahwa siklus pemanasan bertekanan-pendinginan dapat meningkatkan kadar amilosa dan menurunkan kadar amilopektin pati Campolay meskipun tidak signifikan $(p<0.05)$ sebagaimana yang ditunjukkan pada Gambar 4. Peningkatan kadar amilosa pada tepung Campolay termodifikasi disebabkan oleh depolimerisasi molekul amilosa dan amilopektin. Selama autoclaving, kemungkinan terjadi degradasi amilosa rantai panjang menjadi fraksi amilosa rantai pendek yang berakibat pada peningkatan kandungan amilosa pada pati garut termodifikasi tersebut (Shin et al. 2004). Kemungkinan lainnya adalah selama pemanasan molekul amilopektin (terutama rantai pendek terluar) pada daerah kristalin 
terdegradasi sehingga dihasilkan amilosa rantai pendek dan akibatnya kadar amilosa yang terukur juga semakin meningkat (Faridah et al., 2013).

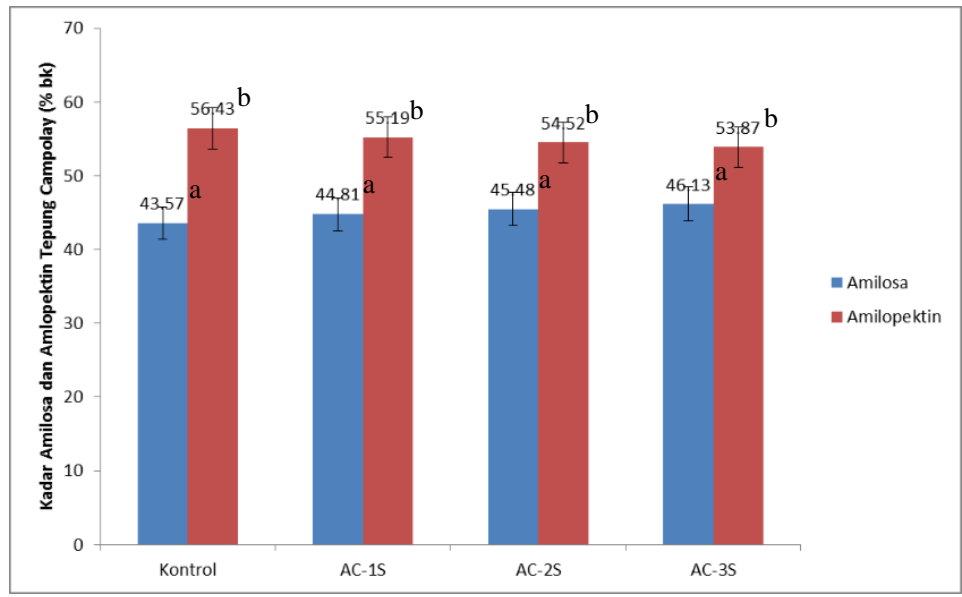

Gambar 4. Pengaruh siklus pemanasan bertekanan-pendinginan terhadap kadar amilosa dan amilopektin tepung Campolay

Huruf yang berbeda pada diagram batang menunjukkan nilai yang berbeda nyata dengan taraf nyata $95 \%$, ( $a=$ 5\%), setelah dilakukan uji Duncan pada SPSS 17.0

\section{Kadar RDS dan SDS Tepung Campolay Termodifikasi}

Pati dapat dikelompokkan menjadi dua yaitu pati yang cepat dicerna atau rapid digestible starch (RDS) dan pati yang lambat dicerna atau slowly digestible starch(SDS). RDS merupakan komponen pati yang dicerna oleh enzim pencernaan dengan cepat dalam kurun waktu 20 menit. RDS merupakan fraksi pati yang menyebabkan kenaikan glukosa darah setelah makanan masuk ke dalam saluran pencernaan (Englyst et al., 1992). Sementara itu pati lambat cerna (SDS) merupakan komponen pati yang dapat dicerna oleh sistem pencernaan dalam usus halus secara sempurna selama kurun waktu 120 menit (Englyst et al. 1992).

Hasil penelitian menunjukkan bahwa perlakuan pemanasan bertekanan-pendinginan berpengaruh nyata $(p<0.05)$ dalam menurunkan kadar RDS (pati cepat cerna) dan meningkatkan kadar SDS (pati lambat cerna) pada tepung Campolay sebagaimana yang ditampilkan pada Gambar 5 dan 6 . Semakin banyak siklus pemanasan bertekanan-pendinginan yang diaplikasikan maka akan berdampak pada proses retrogradasi sehingga mengubah struktur RDS pati Campolay yang cepat dicerna menjadi struktur SDS yang lebih lambat dicerna oleh enzim a-amilase.

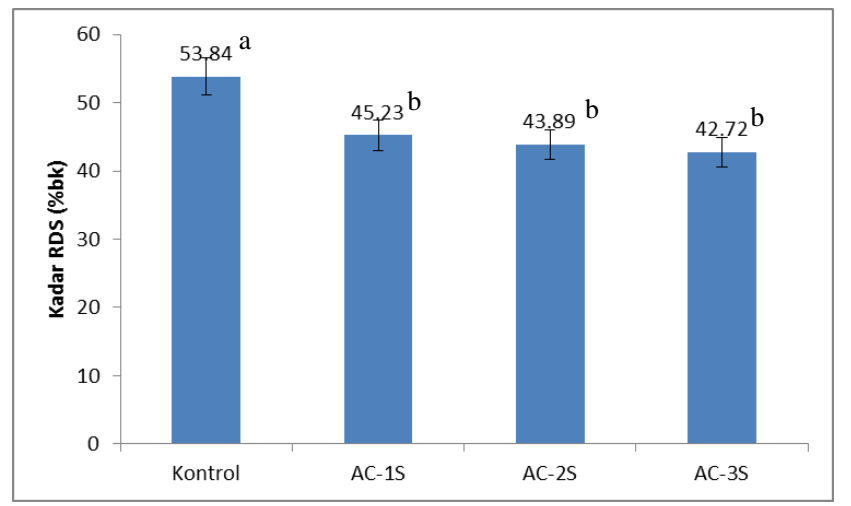

Gambar 5. Pengaruh siklus pemanasan bertekanan-pendinginan terhadap kadar RDS tepung Campolay

Huruf yang berbeda pada diagram batang menunjukkan nilai yang berbeda nyata dengan taraf nyata $95 \%$, ( $a=$ 5\%), setelah dilakukan uji Duncan pada SPSS 17.0

64 R. Haryo Bimo Setiarto, Lia Amalia, Yusdianti Febriani, Tiana Fitrilia, Nunuk Widhyastuti

Pengaruh Siklus Pemanasan Bertekanan-Pendinginan Terhadap Komposisi Kimia dan Kualitas Biologi Tepung Campolay (Pouteria campheciana) 


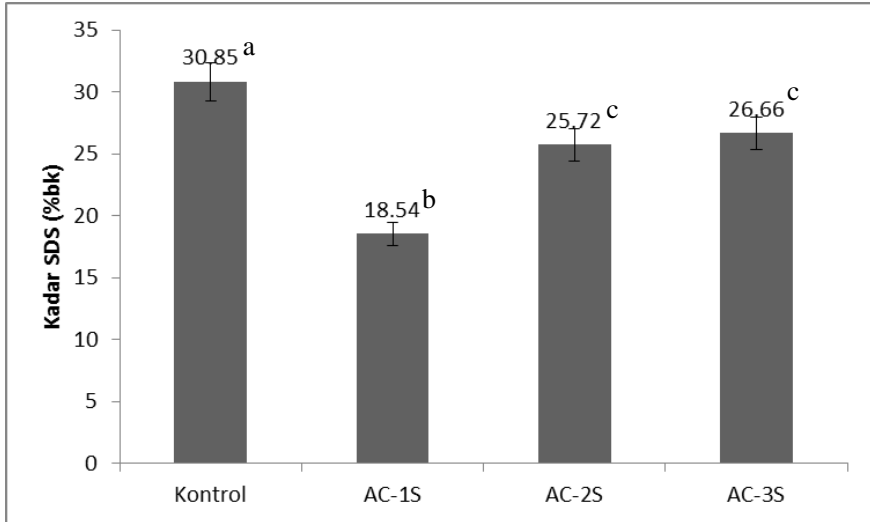

Gambar 6. Pengaruh siklus pemanasan bertekanan-pendinginan terhadap kadar SDS tepung Campolay

Huruf yang berbeda pada diagram batang menunjukkan nilai yang berbeda nyata dengan taraf nyata $95 \%$, ( $a=$ 5\%), setelah dilakukan uji Duncan pada SPSS 17.0

Pemanasan suspensi pati diatas suhu gelatinisasinya menyebabkan terjadinya pemutusan (disosiasi) ikatan hidrogen dari struktur double helix amilopektin, pelelehan (melting) bagian kristalit dan pelepasan amilosa dari granulanya (amylose leaching) (Mutungi etal. 2009). Selanjutnya, terjadi proses pendinginan yang menyebabkan pati teretrogradasi dan terkristalisasi. Pati yang telah menjadi gel akan menjadi endapan kristal apabila disimpan pada kondisi dingin. Selama retrogradasi, molekul pati kembali membentuk struktur kompak yang distabilkan dengan adanya ikatan hidrogen (Sajilata et al. 2006). Retrogradasi pati terutama disebabkan oleh molekul amilosa, karena pembentukan ikatan hidrogen antar molekul amilosa lebih mudah terbentuk. Semakin banyak fraksi amilosa yang keluar dari granula selama proses gelatinisasi, maka semakin banyak pati teretrogradasi yang terbentuk selama proses retrogradasi yang bertanggung jawab pada pembentukan SDS (Srichuwong et al., 2005).

\section{Kadar RS Tepung Campolay Termodifikasi}

Perlakuan pemanasan bertekanan-pendinginan berpengaruh nyata $(p<0,05)$ dalam meningkatkan kadar RS seperti pada Gambar 7. Siklus pemanasan bertekanan-pendinginan memiliki pengaruh yang signifikan $(p<0,05)$ dalam meningkatkan kadar RS tepung Campolay termodifikasi jika dibandingkan dengan perlakuan kontrol. Hal ini dibuktikan oleh perlakuan 1 siklus pemanasan bertekanan-pendinginan (AC-1S) yang meningkatkan kadar RS sebesar 2,4 kali lipat (dari 15,31 \% menjadi 36,23 \%) jika dibandingkan dengan kontrol. Sementara itu perlakuan 2 siklus dan 3 siklus pemanasan bertekanan-pendinginan (AC-2S) masing-masing memberikan peningkatan kadar RS sebesar 2 kali lipat jika dibandingkan dengan kontrol seperti pada Gambar 7. Perlakuan 2 siklus dan 3 siklus pemanasan bertekanan-pendinginan (AC-3S) relatif tidak berbeda nyata $(p<0,5)$ dalam meningkatkan kadar RS pada tepung Campolay seperti pada Gambar 7. Penelitian lanjutan perlu dilakukan untuk mengevaluasi sifat prebiotik (efek dan indeks prebiotik, serta aktivitas prebiotik) maupun sifat amilografi dari komponen RS tepung Campolay. Setiartoet al., (2018) melaporkan bahwa fermentasi kultur campuran bakteri asam laktat (Lactobacillus plantarum D-240 dan Leuconostoc mesenteroides SU-LS 67) penghasil amilase dan pululanase yang dilanjutkan dengan perlakuan 1 siklus pemanasan bertekanan-pendinginan mampu meningkatkan kadar RS pada tepung talas 2,8 kali lipat jika dibandingkan dengan perlakuan kontrol. 


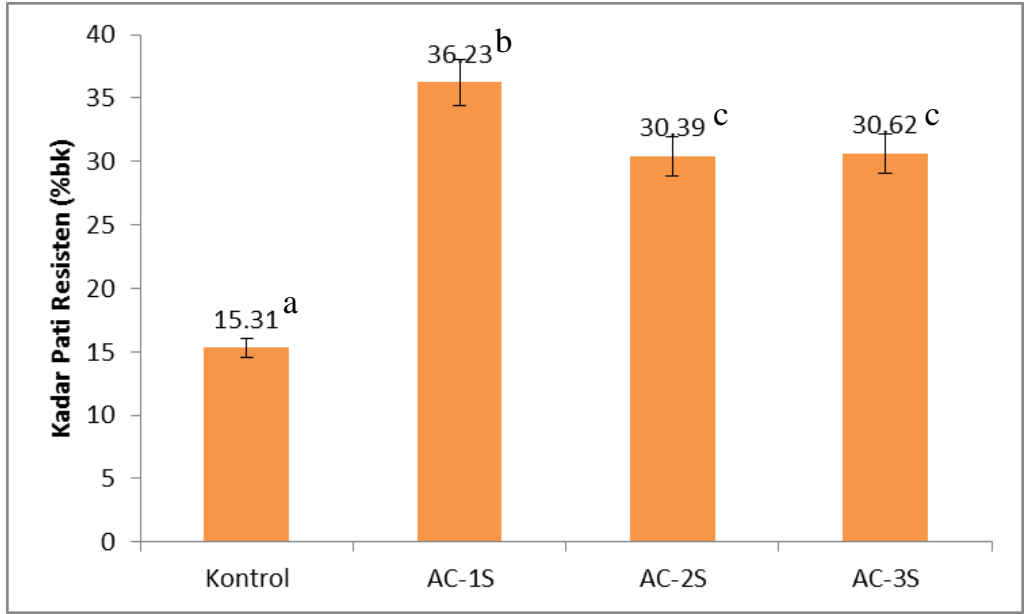

Gambar 7. Pengaruh siklus pemanasan bertekanan-pendinginan terhadap kadar resistant starch tepung Campolay

Huruf yang berbeda pada diagram batang menunjukkan nilai yang berbeda nyata dengan taraf nyata $95 \%$, ( $a=$ 5\%), setelah dilakukan uji Duncan pada SPSS 17.0

Proses pembentukan RS dalam bahan pangan dipengaruhi oleh sifat alami pati (kristalinitas pati, struktur granula, rasio amilosa dan amilopektin, retrogradasi amilosa, pengaruh panjang rantai amilosa, linearisasi amilopektin), interaksi pati dengan komponen lain (protein, serat pangan, inhibitor enzim, ion, gula, lipid atau emulsifier), konsentrasi enzim pululanase, konsentrasi pati, suhu pemanasan, siklus pemanasan bertekanan dan pendinginan, kondisi penyimpanan dan adanya lipid atau substansi bermolekul rendah seperti gula (Sajilata et al. 2006). Proses pembentukan RS didahului oleh mekanisme gelatinisasi dan retrogradasi pati. Onyango et al. (2006) melaporkan bahwa suhu pemanasan dan air berlebih yang dapat menyebabkan gelatinisasi sehingga granula pati membengkak dan bersifat irreversible adalah pada suhu diatas suhu gelatinisasi (suhu karakteristik) dengan perbandingan air dengan pati yang berlebih (>90\% b/b). Pati tergelatinisasi kemudian mengalami penurunan suhu sehingga dapat mengkristal kembali, peristiwa ini disebut dengan retrogradasi (Nurhayati et al. 2014). Retrogradasi pati terutama dipercepat dengan penyimpanan gel pati pada suhu rendah, yaitu umumnya pada suhu sekitar $4^{\circ} \mathrm{C}$. Pongjanta et al. (2009) melaporkan bahwa pendinginan pada suhu $4^{\circ} \mathrm{C}$ memberikan efek yang sangat nyata terhadap peningkatan kadar RS karena pada suhu tersebut lebih banyak pati yang mengalami retrogradasi.

Peningkatan RS terutama diakibatkan oleh terjadinya retrogradasi pada pati Campolay. Pada saat tahap retrogradasi, molekul pati berupa amilosa maupun amilopektin akan saling berikatan kembali secara double helix sehingga membentuk struktur yang rapat dan stabil oleh ikatan hidrogen (Sajilataet al., 2006 dan Vatanasuchart et al.,2012). Granula pati yang kaya akan amilosa mempunyai kemampuan mengkristal yang lebih besar yang disebabkan oleh lebih intensifnya ikatan hidrogen. Hal ini mengakibatkan pati tidak mengembang atau mengalami gelatinisasi sempurna pada waktu pemasakan. Pembentukan RS terjadi karena granula pati mengalami gelatinisasi. Granula rusak akibat proses pemanasan basah dan terjadi pelepasan amilosa dari granula ke dalam larutan. Pada saat pendinginan, rantai polimer terpisah sebagai ikatan ganda (double helix) dan mengalami pembentukan kembali ke struktur awalnya secara perlahan membentuk struktur kompak yang distabilkan oleh ikatan hidrogen (Sajilata et al., 2006).

\section{Daya Cerna Pati in-vitro Tepung Campolay Termodifikasi}

Daya cerna pati adalah tingkat kemudahan suatu jenis pati untuk dapat dihidrolisis oleh enzim a-amilase menjadi unit-unit monomer yang lebih sederhana (Nugent, 2005).Daya cerna 
pati dihitung sebagai hasil persentase relatif terhadap pati murni. Pati murni diasumsikan dapat dicerna dengan sempurna dalam saluran pencernaan. Daya cerna pati memiliki hubungan yang terbalik dengan kadar RS pada pangan. Semakin besar kadar RS, maka semakin kecil daya cerna pati bahan pangan tersebut (Anderson et al., 2002).

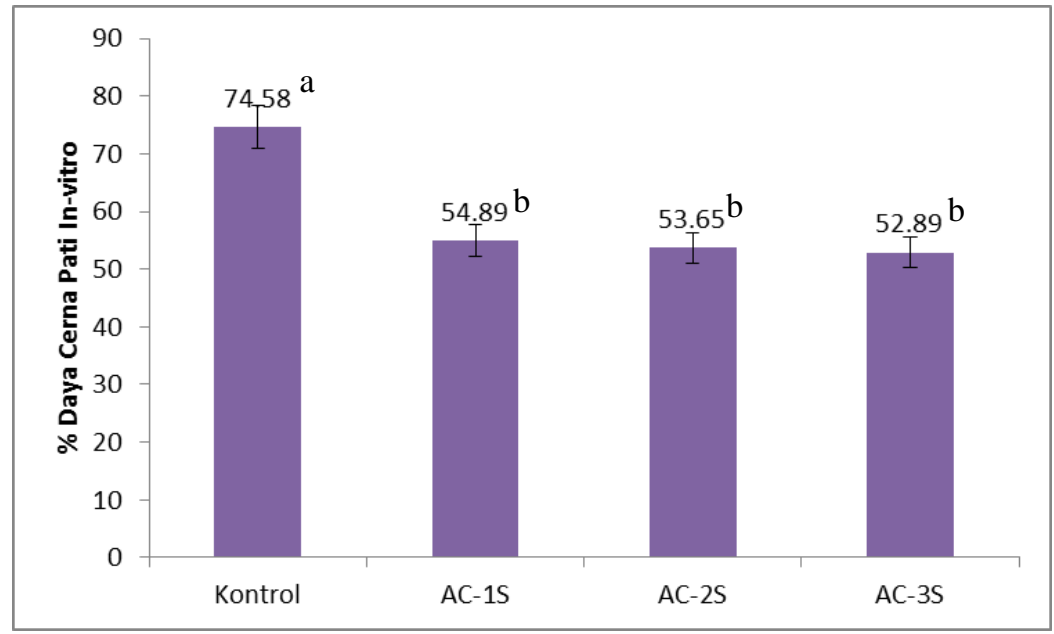

Gambar 8. Pengaruh siklus pemanasan bertekanan-pendinginan terhadap daya cerna pati tepung Campolay

Huruf yang berbeda pada diagram batang menunjukkan nilai yang berbeda nyata dengan taraf nyata $95 \%$, $(a=$ 5\%), setelah dilakukan uji Duncan pada SPSS 17.0

Pemanasan bertekanan-pendinginan berpengaruh nyata terhadap penurunan daya cerna pati tepung Campolay termodifikasi. Hal ini ditunjukkan pada perlakuan 1, 2 dan 3 siklus pemanasan bertekanan-pendinginan (AC-1S, AC-2S, AC-3S) yang terbukti berpengaruh signifikan $(p<0,05)$ dalam menurunkan daya cerna pati tepung Campolay jika dibandingkan dengan kontrol seperti pada Gambar 8. Penurunan daya cerna pada perlakuan pemanasan bertekanan-pendinginan berhubungan dengan meningkatnya kadar RS akibat proses retrogradasi sebagaimana penelitian Faridah et al. (2013) dan Sugiyono et al. (2009). Tepung Campolay dengan perlakuan AC-1S, AC-2S, AC-3S dapat diaplikasikan sebagai sumber prebiotik dan bahan pangan fungsional bagi penderita penyakit diabetes karena daya cernanya yang rendah sehingga lebih lambat diserap oleh tubuh. Dari penelitian ini diketahui bahwa semakin rendah daya cerna in-vitro tepung Campolay modifikasi maka akan semakin meningkatkan pembentukan RS.

\section{KESIMPULAN}

Perlakuan siklus pemanasan bertekanan pendinginan terbukti mampu meningkatkan kadar RS pada tepung Campolay termodifikasi. Perlakuan 1 siklus pemanasan bertekananpendinginan (AC-1S) menghasilkan peningkatan kadar RS tertinggi (36,23 \%bk) jika dibandingkan dengan perlakuan lainnya dan dapat meningkatkan kadar RS sebesar 2,4 kali lipat jika dibandingkan dengan perlakuan kontrol (15,31 \% bk). Peningkatan kadar RS pada tepung Campolay termodifikasi berdampak pada penurunan daya cernanya.

\section{UCAPAN TERIMA KASIH}

Terima kasih yang sebesar-besarnya penulis sampaikan kepada ibu Kasirah dan seluruh staf peneliti laboratorium Mikrobiologi Pangan Pusat Penelitian Biologi LIPI yang telah membantu baik secara teknis maupun non teknis sehingga penelitian ini berjalan lancar. 


\section{DAFTAR PUSTAKA}

Anderson AK, Guraya HS, James C, Salvaggio L. Digestibility and pasting properties of rice starch heat-moisture treated at the melting temperature (Tm). J Starch/Stärke.2002; 54:401-409.

Aseervatham GS, Sivasudha T, Sasikumar JM, Christabel PH, Jeyadevi R, Ananth DA.Antioxidant and hepatoprotective potential of Pouteria campechiana on acetaminophen-induced hepatic toxicity in rats. J. Physiol. Biochem. 2013; 70(1):1-14.

Bastos DM, Monaro E, Siguemoto E, Sefora M. Maillard Reaction Products in Processed Food: Pros dan Cons. Food Industrial Processes- Methods andEquipment, Dr. Benjamin Valdez (Ed). 281-300 InTech. 2012.

Birt DF, Boylston T, Hendrich S, Lane J, Hollis J, Li L, McClelland J, Moore S, Phillips GJ, Rowling M, Schalinske K, Scott MP, Whitley MP. Resistant Starch: Promise for Improving Human Health. Advances in Nutrition.2013; 4(6): 587-601.

Chan-Zapata I, Canul-Canche J, Fernández-Martín K, Martín-Quintal Z, Torres-Romero JC, Lara-Riegos JC, Ramírez-Camacho MA, Arana-Argáeza VE. Immunomodulatory effects of the methanolic extract from Pouteria campechiana leaves in macrophage functions. Food and Agricultural Immunology. 2018; 29(1): 386-399.

Costa DSA, Wondracek DC, Lopes RM, Vieira RF, Ferreira FR. Carotenoids composition of canistel (Pouteria campechiana (Kunth) Baehni). Rev. Bras. Frutic.2010; 32(3):903-906.

de Lanerolle MS, Priyadarshani AMB, Sumithraarachchi DB, Jansz ER. The carotenoids of Pouteria campechiana (sinhala: ratalawulu). Journal of the National Science Foundation of Sri Lanka. 2008; 36(1): 95-98.

Elsayed AM, El-Tanbouly ND, Moustafa SF, Abdou RM,Sally A, El Awdan W. Chemical composition and biological activities of Pouteria campechiana (Kunth) Baehni.Journal of Medicinal Plants Research.2016; 10(16): 209-215.

Englyst HN, Kingman SM, Cummings $\mathrm{JH}$. Classification and measurement of nutritionally important starch fractions. European Journal of Clinical Nutrition.1992; 46: 533-550.

Faridah DN, Rahayu WP, Apriyadi MS. Modifikasi Pati Garut (Marantha Arundinacea) dengan Perlakuan Hidrolisis Asam dan Siklus Pemanasan-Pendinginan Untuk Menghasilkan Resistant starch Tipe 3. J Teknol Indus Pangan.2013; 23 (1): 61-69.

Hernandez CLC, Villaseñora IM, Joseph E, Tolliday N. Isolation and Evaluation of Antimitotic Activity of Phenolic Compounds from Pouteria campechiana Baehni. Philippine Journal of Science. 2008; 137 (1): 1-10.

Karim AA, Norziah MH, Seow CC. Methods for the study of starch retrogradation. Food Chemistry.2000; 71: 9-36.

Kubola J, Siriamornpun S, Meeso N. Phytochemicals, vitamin C and sugar content of Thai wild fruits. Food Chem. 2010; 126(3):972-981.

Leong $\mathrm{YH}$, Karim AA, Norziah MH. Effect of pullulanase debranching of sago (Metroxylon sago) starch at subgelatinization temperature on the yield of resistant starch.Starch/Starke.2007; 59: 21-32.

Moongngarm A. Chemical Compositions and Resistant Starch Content in Starchy Foods. American Journal of Agricultural and Biological Sciences.2013; 8 (2): 107-113.

Mutungi C, Rosta F, Onyango C, Jarosa D, Rohma H. Crystallinity, thermal and morphological characteristics of resistant starch type III Produced by hydrothermal treatment of debranched cassava starch. Starch/Starke.2009; 61:1-12.

Nugent AP. Health properties of resistant starch.Br.Nutr. Foundation Nutr.Bull.2005; 30: 2754.

Nurhayati, Jenie BSL, Widowati S, Kusumaningrum HD. Komposisi Kimia dan Kristalinitas Tepung Pisang Termodifikasi Secara Fermentasi Spontan dan Siklus Pemanasan Bertekanan-Pendinginan. Agritech.2014; 34 (2): 146-150. 
Onyango C, Bley $\mathrm{T}$, Jacob A, Henle T, Rohm $\mathrm{H}$. Influence ofincubation temperature and time onresisten starch type III formation fromautoklaf and acid-hydroysed cassavastarch. Carbohydrate Polymers, 2006; 66:494-499.

Pongjanta J, Utaipattanaceep O, Naivikul, Piyachomkwan K. Effect of preheated treatments on physicochemical properties of resistant starch type III from pullulanase hydrolysis of high amylose rice starch. American Journal of Food Technology. 2009; 4(2): 79-89.

Ragasa CY, Labacladoa LM, Rideout JA. Triterpenes and Sterol from Pouteria campechiana. The Manila Journal of Science. 2011; 6(2):1-7.

Sajilata MG, Rekha SS, Puspha RK. Resistant starch a review. J Comprehensive Rev in Food Sci and Food Safety.2006; 5: 1-17.

Setiarto RHB, Jenie BSL, Faridah DN, Saskiawan I. Kajian Peningkatan Resistant starch yang Terkandung dalam Bahan Pangan Sebagai Sumber Prebiotik.Jurnal IImu Pertanian Indonesia.2015; 20(3): 191-200.

Setiarto RHB, Jenie BSL, Faridah DN, Saskiawan I, Sulistiani. Effect oflactic acid bacteria fermentation and autoclaving-cooling for resistant starchand prebiotic properties of modified taro flour.International Food Research Journal. 2018; 25(4): 1702-1708.

Shin SI, Byun J, Park KH, Moon TW.Effect of partial acid hydrolysisand heat-moisture treatment onformation of resistant tuber starch.Cereal Chemistry.2004; 81: 194-198.

Srichuwong S, Sunarti TC, Mishima T, Isono N, Hisamatsu M. Starches from different botanical sources I: Contribution of amylopectin fine structure to thermal properties and enzyme digestibility. Carbohydrate Polymers.2005; 60: 529-538.

Sugiyono, Pratiwi R, Faridah DN. Modifikasi Pati Garut dengan Perlakuan Siklus Pemanasan Suhu Tinggi-Pendinginan Untuk Menghasilkan Resistant starch Tipe III. J Teknol Indus Pangan.2009; 20(1): 17-24.

Susilawati M. Hubungan Konsentrsi Bahan Pengisi Dan Pengeringan Tehadap Karakteristik Fruit Leather Buah Campolay (Pouteria Campechiana). [Skripsi].Bandung.Fakultas Teknik Universitas Pasundan, 2015.

Vatanasuchart N, Niyomwit B, Wongkrajang K. Resistant starch content, in vitro starch digestibility and physico-chemical properties of flour and starch from Thai bananas. Maejo Int. J. Sci. Technol. 2012; 6(2): 259-271.

Yadav BS, Sharma A, Yadav RB. Studies on Effect of Multiple Heating/Cooling Cycles on the Resistant Starch Formation in Cereals, Legumes and Tubers. International Journal ofFood Science Nutrition.2009; 60(4): 258-272.

Zaragoza EF, Riquelme-Navarrete MJ, Sanchez-Zapata E, Perez-Alvarez JA. Resistant starch as functional ingredient: A review. Food Research International. 2010; 43(4): 931-940. 